\title{
Social support, self-efficacy and level of physical activity of students aged 13-15 years
}

\section{Apoio social, autoeficácia e o nível de atividade física em escolares de 13 a 15 anos}

\author{
Jhonatan Gritten Campos \\ (D) https://orcid.org/0000-0002-3039-2688 \\ Eliane Denise Araújo Bacil 1,2 \\ (D) https://orcid.org/0000-0002-8672-395X \\ Thiago Silva Piola 1,3 \\ (D) https://orcid.org/0000-0002-6081-0510 \\ Michael Pereira da Silva ${ }^{1,4}$ \\ (D) https://orcid.org/0000-0002-7628-3997 \\ Ana Beatriz Pacífico \\ (D) https://orcid.org/0000-0001-9719-0792 \\ Wagner de Campos \\ (D) https://orcid.org/0000-0003-3979-1017
}

Abstract - The aim of this study was to verify the relationship, the population attributable fraction (PAF) and the relative risk reduction (RRR) of social support and self-efficacy with level of physical activity in students. Probabilistic cross-sectional study with 1,472 students aged 13-15 years. Gender, age, social support from parents and friends, self-efficacy and levels of physical activity were evaluated through questionnaires. Data analysis was performed using Poisson regression with robust variance, PAF and RRR, adopting $\mathrm{p} \leq 0.05$. A total of $56.1 \%$ $(\mathrm{n}=826)$ of students were considered active, boys $(68.7 \%)$ presenting the largest proportion. Social support from parents was positively associated with physical activity in boys (PR: 1.28, 95\% CI: 1.12-1.48, PAF = 21.88) and girls (PR: 2.00; 95\%CI: 1.59-2.51, PAF = 50.00). Social support from friends was positively associated with physical activity in boys (PR: $1.34,95 \% \mathrm{CI}$ : 1.16-1.54, PAF $=25.37)$ and girls (PR: 1.32, 95\%CI: 1.06-1.64, PAF = 24.24). Self-efficacy was not associated with physical activity. Social support was associated with levels of physical activity, and PAF indicated that the absence of high social support from parents and friends might reduce the level of physical activity in adolescents.

Key words: Adolescent; Motor activity; Self-efficacy; Social support.

Resumo - Objetivou-se verificar a relação, a fração atribuivel populacional (FAP) e a redução relativa do risco (RRR) do apoio social e autoeficácia com o nivel de atividade física em escolares. Estudo transversal probabilístico com 1472 escolares de 13 a 15 anos. Foram avaliados sexo, idade, apoio social dos pais e dos amigos, autoeficácia e nivel de atividade física através de questionários. Para análise dos dados utilizou-se regressão de Poisson com variância robusta, $F A P$ e $R R R$, adotando $p \leq 0,05$. Foram considerados ativos $56,1 \%(n=826)$ dos escolares, sendo os meninos $(68,7 \%)$ em maior proporção. $O$ apoio social dos pais foi positivamente associado à prática de atividades física dos meninos (RP: 1,28; IC95\%: 1,12-1,48; FAP=21,88) e das meninas (RP: 2,00; IC95\%: 1,59-2,51; FAP=50,00). O apoio social dos amigos foi positivamente associado à prática de atividades físicas dos meninos (RP: 1,34; IC95\% 1,16-1,54; FAP=25,37) e das meninas (RP: 1,32; IC95\%: 1,06-1,64; FAP=24,24). $A$ autoeficácia não se associou com atividade física. $O$ apoio social apresentou-se associado com o nível de atividade física, $e$ as análises da FAP indicaram que sem o elevado apoio social dos pais e amigos pode haver uma redução do nivel de atividade física em adolecentes.

Palavras-chave: Adolescente; Apoio social; Atividade motora; Autoeficácia.
1 Federal University of Paraná. Curitiba, PR. Brazil.

2 Positivo University. Curitiba, PR Brazil.

3 Claretiano University Center. Curitiba, PR. Brazil.

4 Midwestern State University. Guarapuava, PR. Brazil

Received: August 15, 2018 Accepted: April 22, 2019

How to cite this article Campos JG, Bacil EDA, Piola TS, Silva MP, Pacífico AB, Campos W. Social support, self-efficacy and level of physical activity of students aged 13-15 years. Rev Bras Cineantropom Desempenho Hum 2019, 21:e58684. DOl: http://dx.doi.org/10.1590/19800037.2019v21e58684.

Copyright: This work is licensed under a Creative Commons Attribution 4.0 International License. 


\section{INTRODUCTION}

The literature highlights the importance of physical activity (PA) in adolescence ${ }^{1}$; however, most adolescents do not meet minimum PA recommendations for health as indicated in the Study of Cardiovascular Risks in Adolescents (ERICA) ${ }^{2}$ with Brazilian adolescents aged 12-17 years, indicating that about $54.3 \%$ of adolescents have insufficient PA practice.

The identification of factors that may influence PA practice is pointed as essential information for the development of programs that promote the habitual practice of this behavior in adolescents ${ }^{3}$. Among these factors, social support (SS) and self-efficacy represent significant influence for different health-related aspects such as: how to control body weight and fat percentage, cardiovascular system and psychological well-being improvement, which are important factors in PA promotion strategies among adolescents ${ }^{4}$.

SS is defined as the incentive for PA practice offered by parents, relatives, siblings and / or friends ${ }^{5}$, and self-efficacy refers to the confidence of action to perform $\mathrm{PA}^{6}$. In a systematic review by Lisboa et al. ${ }^{7}$ involving adolescents aged 14-19 years in cross-sectional and longitudinal studies, the authors point out that SS from parents and friends was associated with PA practice in adolescents of both sexes. Self-efficacy corresponds to behaviors that are learned through observation, positive reinforcement and perception of success and failure ${ }^{8}$ and its application in the PA practice context refers to the individual's ability to continue to practice PA even in the onset of obstacles that may limit the performance of this behavior. The literature shows positive associations of self-efficacy with PA practice, since the elevation of its levels may be an important component of strategies to promote PA in this population ${ }^{8}$.

There are several studies indicating association of SS and self-efficacy with level of PA among adolescents ${ }^{8-10}$, but there are no studies in the national and international literature with estimates of population attributable fraction (PAF) and relative risk reduction (RRR) in the relationship of SS and self-efficacy with level of PA in adolescents. PAF would allow estimating how much the practice of regular PA can be decreased without exposure to SS and self-efficacy. RRR would allow estimating how much regular PA practice can be reduced with SS exposure and self-efficacy. Thus, $\mathrm{PAF}$ and RRR estimates could go beyond these associations, showing the repercussion and consequences of exposure in relation to the outcome ${ }^{11}$.

In this context, the aim of this study was to verify the relationship of population attributable fraction and the relative reduction of the risk of social support and self-efficacy with level of physical activity in male and female students from Curitiba / PR.

\section{METHOD}

This research is part of the project entitled: "Correlates of physical activity 
and sedentary behavior of students aged 11-15 years from public schools of Curitiba / PR"12. This is a cross-sectional study conducted in 10 public schools of Curitiba, Paraná, from March to May 2016. Individuals of both sexes, enrolled in urban elementary schools from the $8^{\text {th }}$ and $9^{\text {th }}$ grades and high school students from the $1^{\text {st }}$ year of the day shift were part of the study. The probabilistic sample was selected from the multi-stage sampling process in three stages. Initially, all state schools were listed and stratified according to each of the ten administrative regions of the city of Curitiba / PR. Then, a school was drawn in each administrative district of the city. Finally, a simple random selection of two classes of each year was made, according to the number of students, separated by sex.

Based on literature ${ }^{13,14}$, for the sample calculation considering a population of 50,223, PA prevalence of $50 \%$ in adolescents was considered, confidence level of $95 \%$ ( $\mathrm{sd}=1.96$ ), sampling error of 4.0 percentage points, design effect of 1.5 and increase of $30 \%$ for losses and refusals ${ }^{15}$. The minimum sample was estimated at 1,080 students. A total of 1,615 schoolchildren were evaluated. Of these, 57 were outside the age group of interest, two were physically disabled, one was a pregnant woman and 18 did not complete all questionnaire items. However, 22 students incorrectly completed it, 26 did not return the Informed Consent Form (ICF) signed by parents / guardians and 17 gave up participating in the study. Thus, the final sample consisted of 1,472 students of both sexes aged 13-15 years. The calculation of the a posteriori statistical power of the sample, considering $\alpha$ of 0.05 and $\beta$ of 0.20 , indicates that 1,472 subjects can identify prevalence ratios above 1.17 as risk and below 0.85 as protection.

Data collection was performed by a trained team from the Center for Studies in Physical Activity and Health (CEAFS - UFPR). A pilot study was previously conducted to train evaluators on the procedures of this study, aiming to improve the reliability of data collection.

The study was approved by the Human Research Ethics Committee (CEP) of the Federal University of Paraná (protocol No. 722.529; CAAE 30350514.3.0000.0102), according to Resolution of the National Health Council (CNS) 466/2012.

With the CEP authorization document, researchers contacted the selected schools requesting authorization to conduct the study, scheduling days of data collection as well as selecting classes that would participate in the research. A visit was scheduled to the school to present the objectives and relevance of the study, as well as clarification of possible doubts to the school board and faculty. Only one school refused to participate, and a new draw was held for a school within the same region of the city.

On the day before data collection, students in the selected groups were given the ICF so that parents or guardians could authorized their children to participate in the research and the written informed consent form (WICF). These documents should be signed and returned on the day of data collection so that students could participate in the study. The following day, the questionnaire was individually completed in the class- 
room with the presence of researchers and teacher responsible for the class.

SS and self-efficacy for PA were measured by a four-point Likert scale ${ }^{16}$. The SS questionnaire is divided into two sessions (parents and friends). In each session, the six types of SS are specified: stimulate, practice together, transport, watch, comment and talk about. Among friends, the transport variable was replaced by invite. Based on a typical or normal week, students reported the frequency (never, rarely, frequently, always) with which parents and friends encourage them to engage in physical activity. The PA self-efficacy scale has 10 items, divided into two sessions in the questionnaire: SS and reasons for PA (tiredness and stress, lack of company, lack of motivation, among others) and resources for PA practice (lack of places and instruction to practice, among others). These questions were classified as: 1 (strongly disagree), 2 (disagree), 3 (agree) and 4 (strongly agree $)^{16}$. Subsequently, a sum of these scores was made. SS and self-efficacy scales were classified by tertile: $1^{\text {st }}$ tertile (low), $2^{\text {nd }}$ tertile (moderate) and $3^{\text {rd }}$ tertile (high). SS and self-efficacy scales have satisfactory validity and reproducibility, and the questionnaire had intraclass correlation coefficient (ICC) for SS of 0.92 (95\% CI: 0.91-0.93) and for self-efficacy of 0.75 (95\% CI: $0.71-0.79)^{17}$.

The PA questionnaire analyzed in the present study was proposed by Farias Junior et al. ${ }^{18}$, which is an adaptation of the Self-Administered Physical Activity Checklist ${ }^{19}$, consisting of a list of 24 moderate to vigorous physical activities (> 3METS), with the possibility of adding two more. In determining the level of physical activity, the sum of the product of the time spent in each of the physical activity by the respective frequencies of practice was considered. Schoolchildren with PA practice equal to or greater than 420 minutes / week were considered sufficiently active and those who exercised for a shorter time were insufficiently active ${ }^{20}$. This questionnaire presented satisfactory validity and reproducibility $(\mathrm{ICC}=$ 0.88; 95\% CI: 0.86-0.90) ${ }^{21}$.

For data analysis, considering the influence of SS and self-efficacy on PA different in boys and girls, categorical variables were described through absolute and relative frequency, total and stratified by sex. The chi-square test was used for gender comparisons. SS and self-efficacy variables were analyzed by measures of central tendency and dispersion (mean and standard deviation) and divided by tertiles. To verify the association of SS and self-efficacy with PA, Poisson regression analysis with robust variance was used and then adjusted for all independent and control variables (age) with their respective confidence intervals $(95 \% \mathrm{CI})$.

For SS and self-efficacy, PAF was calculated when the prevalence ratio indicated positive association between factor and outcome, and RRR when the prevalence ratio $(\mathrm{PR})$ indicated negative association between factor and outcome, using equations PAF $=\mathrm{PR}-1 \times 100 / \mathrm{RP}$ and $\mathrm{RRR}=1-\mathrm{PR} \times$ 100 , respectively ${ }^{11,22}$. All analyses were performed using the IBM SPSS 24 software, with significance level set at $\mathrm{p} \leq 0.05$. 


\section{RESULTS}

The total sample was composed of 1,615 students, with loss of $8.86 \%$ (n $=143)$, thus, the final sample was composed of 1,472 students $(51.9 \%$, $\mathrm{n}=764$ boys), where the largest proportion of individuals belonged to the age group of $13-14$ years (38.2\% and $38.1 \%$, respectively). Boys had higher SS from parents $(33.0 \%, \mathrm{n}=252)$ and friends $(48.8 \%, \mathrm{n}=373)$ for PA compared to girls. In contrast, girls had higher self-efficacy $(39.7 \%$, $\mathrm{n}=281)$ for PA compared to boys. Most students $(56.1 \%, \mathrm{n}=826)$ were considered active, with boys $(68.7 \%, \mathrm{n}=525)$ in a higher proportion ( $\mathrm{Ta}-$ ble 1). SS scores ranged from 12 to 48 , averaging 25.41 ( $\mathrm{SD}=8.26$ ), for self-efficacy from 10 to 40 , averaging 22.75 ( $\mathrm{SD}=4.87$ ), and for daily PA 134.1 minutes $(\mathrm{SD}=171.8)$.

Table 1. Distribution of study participants, total and stratified by sex, according to age, social support from parents and friends and self-efficacy, 1,472 students, Curitiba, Brazil, 2016.

\begin{tabular}{|c|c|c|c|c|c|c|c|}
\hline \multirow{2}{*}{ Variable } & \multicolumn{2}{|c|}{ Total } & \multicolumn{2}{|c|}{ Male } & \multicolumn{2}{|c|}{ Female } & \multirow{2}{*}{ p } \\
\hline & $n$ & $\%$ & $n$ & $\%$ & $\mathrm{n}$ & $\%$ & \\
\hline Sex & 1472 & 100 & 764 & 51.9 & 708 & 48.1 & \\
\hline \multicolumn{8}{|l|}{ Age } \\
\hline 13 years & 563 & 38.2 & 269 & 35.2 & 294 & 41.5 & 0.01 \\
\hline 14 years & 561 & 38.1 & 284 & 37.2 & 277 & 39.1 & \\
\hline 15 years & 348 & 23.6 & 211 & 27.6 & 137 & 19.4 & \\
\hline \multicolumn{8}{|c|}{ Social support from parents } \\
\hline Low (1st tertile) & 568 & 38.6 & 243 & 31.8 & 325 & 45.9 & 0.01 \\
\hline Moderate (2nd tertile) & 491 & 33.4 & 269 & 35.2 & 222 & 31.4 & \\
\hline High (3rd tertile) & 413 & 28.1 & 252 & 33.0 & 161 & 22.7 & \\
\hline \multicolumn{8}{|c|}{ Social support from friends } \\
\hline Low (1st tertile) & 509 & 34.6 & 208 & 27.2 & 301 & 42.5 & 0.01 \\
\hline Moderate (2nd tertile) & 410 & 27.9 & 183 & 24.0 & 227 & 32.1 & \\
\hline High (3rd tertile) & 553 & 37.6 & 373 & 48.8 & 180 & 25.4 & \\
\hline \multicolumn{8}{|l|}{ Self-efficacy } \\
\hline Low (1st tertile) & 419 & 28.5 & 239 & 31.3 & 180 & 25.4 & 0.01 \\
\hline Moderate (2nd tertile) & 530 & 36.0 & 283 & 37.0 & 247 & 34.9 & \\
\hline High (3rd tertile) & 523 & 35.5 & 242 & 31.7 & 281 & 39.7 & \\
\hline \multicolumn{8}{|l|}{ Level of Physical Activity } \\
\hline Active & 826 & 56.1 & 525 & 68.7 & 301 & 42.5 & 0.01 \\
\hline Insufficiently active & 646 & 43.9 & 239 & 31.3 & 407 & 57.5 & \\
\hline
\end{tabular}

Note. $p<0.05$.

Tables 2 and 3 describe the results of the association of PAF and RRR of SS and self-efficacy with PA level. In the crude analysis, boys with moderate and high SS from parents had prevalence of 20\% (PR: 1.20; 95\% CI: 1.04-1.37) and 42\% (RP: 1.42; 95\% CI: 1.26 - 1.61) higher of being active than students with low SS from parents. In the adjusted analysis, only boys with high SS from parents maintained higher prevalence of being active than boys with low SS from parents (PR: 1.28; 95\% CI: 1.12-1.46). Girls with moderate and high SS from parents showed higher prevalence of 
being active in both crude (PR: 1.80; 95\% CI: 1.45-2.24) (PR: 2.17; 95\% CI: 1, 75-2.69) and adjusted analysis (PR: 1.69; 95\% CI: 1.35-2.11) (RP: 2.00; 95\% CI: 1.59-2.51) compared to girls with low SS.

Regarding support from friends, boys with high SS, both in the crude and adjusted analysis, had prevalence of 44\% (PR: 1.44; 95\% CI: 1.26-1.65) and 34\% (PR: 1.34; 95\% CI: 1.16-1.54) higher of being active than boys who did not receive SS from friends to practice PA. Girls with moderate and high SS from friends had prevalence of 43\% (PR: 1.43; 95\% CI: 1.161.77 ) and $60 \%$ (PR: $1.60 ; 95 \%$ CI: $1.30-1.88$ ) higher of being active than girls with low SS from friends in the crude analysis. The same occurs in the adjusted analysis, where girls with moderate and high SS from friends

Table 2. Relationship between social support and self-efficacy with physical activity in 13 to 15 -year-old male students from Curitiba, Paraná, Brazil, 2016.

\begin{tabular}{|c|c|c|c|c|c|c|c|c|c|c|}
\hline & \multicolumn{2}{|c|}{ Active } & \multicolumn{4}{|c|}{ Crude analysis } & \multicolumn{4}{|c|}{ Adjusted analysis* } \\
\hline & $n$ & $\%$ & PR & $95 \% \mathrm{Cl}$ & PAF (\%) & RRR (\%) & PR & $95 \% \mathrm{Cl}$ & PAF (\%) & RRR (\%) \\
\hline \multicolumn{11}{|l|}{ Support from parents } \\
\hline Low (1st tertile) & 138 & 56.8 & 1.0 & & & & 1.0 & & & \\
\hline Moderate ( $2^{\text {nd }}$ tertile) & 183 & 68.0 & 1.20 & $1.04-1.37$ & 16.67 & - & 1.13 & $0.98-1.30$ & 11.50 & - \\
\hline High (3 $3^{\text {rd }}$ tertile) & 204 & 81.0 & 1.42 & $1.26-1.61$ & 29.58 & - & 1.28 & $1.12-1.46$ & 21.88 & - \\
\hline \multicolumn{11}{|l|}{ Support from friends } \\
\hline Low (1 $1^{\text {st }}$ tertile) & 114 & 54.8 & 1.0 & & & & 1.0 & & & \\
\hline Moderate ( $2^{\text {nd }}$ tertile) & 116 & 63.4 & 1.16 & $0.98-1.36$ & 13.79 & - & 1.13 & $0.96-1.34$ & 11.50 & - \\
\hline High (3rd tertile) & 295 & 79.1 & 1.44 & $1.26-1.65$ & 30.56 & - & 1.34 & $1.16-1.54$ & 25.37 & - \\
\hline \multicolumn{11}{|l|}{ Self-efficacy } \\
\hline Low (1 ${ }^{\text {st }}$ tertile) & 171 & 71.5 & 1.0 & & & & 1.0 & & & \\
\hline Moderate ( $2^{\text {nd }}$ tertile) & 183 & 64.7 & 0.90 & $0.80-1.02$ & - & 10.0 & 0.91 & $0.81-1.02$ & - & 9.00 \\
\hline High ( $3^{\text {rd }}$ tertile $)$ & 171 & 70.7 & 0.99 & $0.88-1.11$ & - & 1.00 & 0.98 & $0.87-1.09$ & - & 2.00 \\
\hline
\end{tabular}

Note. PR: prevalence ratio; $95 \% \mathrm{Cl}$ : 95\% confidence interval; PAF: population attributable fraction; RRR: Relative risk reduction; ${ }^{*}$ adjusted for all independent variables and chronological age.

Table 3. Relationship between social support and self-efficacy with physical activity in 13 to 15 -year-old female students from Curitiba, Paraná, Brazil, 2016.

\begin{tabular}{|c|c|c|c|c|c|c|c|c|c|c|}
\hline & \multicolumn{2}{|c|}{ Active } & \multicolumn{4}{|c|}{ Crude analysis } & \multicolumn{4}{|c|}{ Adjusted analysis* } \\
\hline & $\mathrm{n}$ & $\%$ & PR & $95 \% \mathrm{Cl}$ & $\operatorname{PAF}(\%)$ & RRR (\%) & PR & $95 \% \mathrm{Cl}$ & PAF (\%) & $\begin{array}{c}\text { RRR } \\
(\%)\end{array}$ \\
\hline \multicolumn{11}{|l|}{ Support from parents } \\
\hline Low (1 ${ }^{\text {st }}$ tertile) & 91 & 28.0 & 1.0 & & & & 1.0 & & & \\
\hline Moderate ( $2^{\text {nd }}$ tertile) & 112 & 50.5 & 1.80 & $1.45-2.24$ & 44.44 & - & 1.69 & $1.35-2.11$ & 40.83 & - \\
\hline High ( $3^{\text {rd }}$ tertile) & 98 & 60.9 & 2.17 & $1.75-2.69$ & 53.92 & - & 2.00 & $1.59-2.51$ & 50.00 & - \\
\hline \multicolumn{11}{|l|}{ Support from friends } \\
\hline Low (1 $1^{\text {st }}$ tertile) & 99 & 32.9 & 1.0 & & & & 1.0 & & & \\
\hline Moderate ( $2^{\text {nd }}$ tertile) & 107 & 47.1 & 1.43 & $1.16-1.77$ & 30.07 & - & 1.27 & $1.03-1.57$ & 21.26 & - \\
\hline High (3rd tertile) & 95 & 52.8 & 1.60 & $1.30-1.98$ & 37.50 & - & 1.32 & $1.06-1.64$ & 24.24 & - \\
\hline \multicolumn{11}{|l|}{ Self-efficacy } \\
\hline Low (1 ${ }^{\text {st }}$ tertile) & 73 & 40.6 & 1.0 & & & & 1.0 & & & \\
\hline Moderate ( $2^{\text {nd }}$ tertile) & 108 & 43.7 & 1.08 & $0.86-1.35$ & 7.41 & - & 1.00 & $0.81-1.25$ & - & 0.00 \\
\hline High (3rd tertile) & 120 & 42.7 & 1.05 & $0.84-1.32$ & 4.76 & - & 0.92 & $0.74-1.14$ & - & 8.00 \\
\hline
\end{tabular}

Note. PR: prevalence ratio; $95 \%$ Cl: 95\% confidence interval; PAF: population attributable fraction; RRR: Relative risk reduction; *adjusted for all independent variables and chronological age. 
had prevalence of $27 \%$ (95\% CI: $1.03-1.57)$ and $32 \%$ (95\% CI: $1.06-1.64)$ of being active than girls with low SS from friends.

Regarding the associations of self-efficacy with PA, no significant association was observed for both male and female students.

When calculating PAF based on PR resulting from the adjusted analysis, it was observed for high SS from parents PAF $=21.88$ for males, and for girls, for moderate and high SS from parents PAF $=40.83$ and $\mathrm{PAF}=50.00$, respectively. For high SS from friends, boys presented PAF $=25.37$, and girls, $\mathrm{PAF}=21.26$ and $\mathrm{PAF}=24.24$ for moderate and high SS from friends, respectively.

\section{DISCUSSION}

The present study aimed to verify the relationship between SS and selfefficacy with level of PA in students from Curitiba / PR. The results indicated that SS from parents and friends were associated with higher level of PA, but self-efficacy was not associated. Additionally, the present study aimed to estimate the exposure of SS and self-efficacy at level of PA through PAF measurements, which allowed measuring how much level of PA could decrease without SS exposure and self-efficacy, and RRR that could estimate how much level of PA could decrease with SS exposure and self-efficacy. These analyses indicated that without SS from parents and / or friends both boys and girls would have a large reduction in their level of PA.

In the present study, students who reported having high SS from parents to practice PA had higher prevalence of being active for both males (PR: 1.28; 95\% CI: 1.12-1.46) and females (PR: 2.00; 95\% CI: 1.59-2.51) in the adjusted analysis. SS has been identified as an important correlate for the maintenance of levels of $\mathrm{PA}^{3}$. Our results are similar to those of Prado et al. ${ }^{9}$ performed with 1,469 adolescents aged 14-18 years from the public school system of Curitiba / PR, who indicate that frequent company of family members during PA practice was positively associated with PA of boys (PR: 2.88; 95\% CI: 2.00-4.13) and girls (PR: 3.39 95\% CI: 1.497.69). The study by Cheng et al. ${ }^{10}$, conducted with 2,361 adolescents aged 14-19 years from public and private schools in the city of João Pessoa / $\mathrm{PB}$, showed that the father's PA practice was associated with that of the son $(\beta=0.10<0.001)$ and mother's PA practice with that of the daughter $(\beta=0.08 \mathrm{p}<0.05)$.

It is evident in literature that during adolescence, there is a decline in $\mathrm{PA}^{23}$. Greater contact with friends, especially outside the school environment, seems to influence this decline ${ }^{24}$, as friends who are engaged in PA can increase the likelihood of adolescents practicing $\mathrm{PA}$, and may facilitate the promotion of healthy habits throughout life $\mathrm{e}^{25}$.

The study by Prado et al. ${ }^{9}$ also points out that frequent company of friends is associated with PA for both sexes (boys PR: 5.46; 95\% CI: 2.3312.78; girls PR: 4.06; 95\% CI: 2.22-7.45). Kirby et al. ${ }^{26}$, in a longitudinal study with 1,632 adolescents aged 11-15 year from 4 areas of Scotland, 
point to significant results, as adolescents who received high $\mathrm{SS}$ from friends are 3 times more likely of being active when compared with adolescents receiving low SS from friends (boys: OR: 3.53; 95\% CI: 1.77-7.04 and girls: OR: 3.27; 95\% CI: 1.80-5.92).

As for SS from parents, the results of the present study indicate that SS from friends seems to be an important factor for PA practice among adolescents. Active adolescents tend to have active friends ${ }^{27}$, as they influence to initiate and continue $\mathrm{PA}^{10}$. Adolescents tend to join the same social group, presenting an identity, adapting to their friends' choices and end up exhibiting the same behaviors ${ }^{4,10}$. Thus, identifying the factors associated with low PA facilitates the promotion of intervention programs in adolescents, encouraging the practice of $\mathrm{PA}^{7}$.

Regarding self-efficacy, no associations were found with levels of PA in both boys and girls. However, studies such as Hearst et al. ${ }^{28}$ conducted with 578 adolescents aged 10-16 years in the United States, and Souza et al. ${ }^{8}$ conducted with 1,698 adolescents aged 14-18 years from Curitiba / $\mathrm{PR}$, showed that there is a positive association between self-efficacy and PA practice in adolescents. Self-efficacy is a psychosocial variable, resulting from other factors such as self-esteem and self-confidence, which may influence the relationship with PA and make the comparison with other studies unfeasible ${ }^{29,30}$.

PAF analyses estimated that without high SS from parents for PA, there would be a PA decrease of $21.88 \%$ and $50.0 \%$ for male and female students, respectively. As shown in literature ${ }^{10}$ and in the present study, boys tend to perform more PA, so girls need greater incentive to perform PA, so if there is no influence of SS, there is greater impact on girls in relation to boys. However, without the influence of high SS from friends, the chances of students being active decrease similarly in both sexes. For males, the probability decreases by $25.37 \%$ and for females, the probability decreases by $24.24 \%$ of being active. To belong to a certain group, adolescents tend to adhere to behaviors similar to their peers, indicating that both groups had similar behaviors. These results show that if adolescents have no encouragement from parents and friends to practice PA, they tend to be less active.

The present study has strengths to be mentioned. The research presents $\mathrm{PAF}$ and RRR analyses that go beyond association measures and allow a better understanding of the relationship between SS and self-efficacy on level of PA in a representative sample of 13-15-year-old schoolchildren from Curitiba / PR. The previously tested instruments have adequate psychometric qualities suitable for application in schoolchildren in the age group of this study. However, the study is not free of limitations, the use of self-reported measures to measure SS, self-efficacy and level of PA limit accuracy, and may overestimate responses. A sample of students from public schools only would not allow extrapolation of results to students from private schools and those not regularly enrolled in educational institutions. Finally, studies that investigate psychological variables such as self-esteem, stress, body image as mediators of the association between SS, 
self-efficacy and level of PA should be conducted, as well as longitudinal studies to verify the determinant factor for the reduction of $\mathrm{PA}$ practice in adolescence, and the possible identification of the cause effect relationship, as well as studies with students from private schools and with age groups different from that used in this study.

\section{CONCLUSION}

Based on the findings of the present study, positive association between SS from parents and friends for the practice of PA among students of both sexes was verified. In addition, the present study showed indicators of the impact of this variable on population-level PA, indicating that without high SS from parents, there could be a decrease in the level of PA, especially for girls, and without SS from friends, there would be a similar reduction in the level of PA in both sexes. Regarding self-efficacy, no significant associations were found with PA in both males and females.

\section{COMPLIANCE WITH ETHICAL STANDARDS}

\section{Funding}

This research did not receive any specific grant from funding agencies in the public, commercial, or not-profit sectors. This study was funded by the authors.

\section{Ethical approval}

Ethical approval was obtained from the local Human Research Ethics Committee - Federal University of Paraná and the protocol (no. 722.529; 30350514.3.0000.0102) was written in accordance with standards set by the Declaration of Helsinki.

\section{Conflict of interest statement}

The authors have no conflict of interests to declare.

\section{Author Contributions}

Conceived and designed the experiments: JGC, EDAB, WC. Performed the experiments: JGC and EDAB. Analyzed the data: JGC, EDAB and WC. Contributed with reagents/materials/analysis tools: JGC, EDAB and WC. Wrote the paper: JGC, EDAB, TSP, MPS and ABP.

\section{REFERENCES}

1. Hallal PC, Victora CG, Azevedo MR, Well JCK. Adolescents Physical Activity and Health: A Systematic Review. Sports Med 2006; 36(12): 1019-1030.

2. Cureau FV, Silva TLN, Bloch KV, Fujimori E, Belfort DR, Carvalho KMB de, Leon EB, et al. ERICA: Inatividade física no lazer em adolescentes brasileiros. Rev Saúde Pública 2016; 50(1): 1-11.

3. Bauman AE, Reis RS, Sallis JF, Wells JC, Loos RJF, Martin BW. Correlates of physical activity: why are some people physically active and others not? Lancet 2012; 380(9838):258-271. 
4. Hamilton K, Warner LM, Schwarzer R. The Role of Self-Efficacy and Friend Support on Adolescent Vigorous Physical Activity. Heal Educ Behav 2016;1-7.

5. Glanz K, Rimer B, Viswanath K. Health behavior and health education: health behavior and health education. São Francisco; 2008.

6. Bandura A. Social foundations of thought and action. Englewood Cliffs; 1986.

7. Lisboa T, Silva WL da, Alexandre JM, Beltrame TS. Suporte social da família e amigos para a prática de atividade física de adolescentes: uma revisão sistemática. Cad Saúde Colet 2018; 26(4): 351-359.

8. Souza CA de, Rech CR, Sarabia TT, Añez CRR, Reis RS. Autoeficácia e atividade física em adolescentes de Curitiba, Paraná, Brasil. Cad Saúde Pública 2013; 29(10):2039-2048.

9. Prado CV, Lima AV, Fermino RC, Añez CRR, Reis RS. Apoio social e prática de atividade física em adolescentes da rede pública de ensino: qual a importância da família e dos amigos? Cad Saúde Pública 2014; 30(4):827-838.

10. Cheng LA, Mendonça G, Farias Júnior JC. Physical activity in adolescents: analysis of social influence of parents and friends. J Pediatr 2014; 90(1):35-41.

11. Oliveira Filho PF de. Epidemiologia e Bioestatística: Fundamentos para a Leitura Crítica. Rio de Janeiro: RUBIO; 2015.

12. Bacil EDA. "Correlatos da atividade física e do comportamento sedentário de escolares de 11 a 15 anos da rede pública de ensino de Curitiba/PR". [Tese de doutorado - Programa de Pós-Graduação em Educação Física]. Curitiba (PR): Universidade Federal do Paraná; 2017.

13. Lu C, Ronald S, Sauer PJJ, Sijtsma A, Wiersma R, Huang G, Corpelejin E. Factors of physical activity among Chinese children and adolescents: a systematic review. Int J Behav Nutr Phys Act 2017;14(1):36.

14. Langlois J, Omorou AY, Vuillemin A, Briançon S,, Lecomte E. Association of socioeconomic, school-related and family factors and physical activity and sedentary behaviour among adolescents: multilevel analysis of the PRALIMAP trial inclusion data. BMC Public Health 2017; 17(175): 1-14.

15. Luiz RR, Magnanini MMF. A lógica da determinação do tamanho da amostra em investigações epidemiológicas. Cad Saúde Coletiva 2000; 8(2):9-28.

16. Farias Júnior JC De, Borgatto AF, Hallal PC. Desenvolvimento e validação de um questionário para mensurar fatores associados à atividade física em adolescentes. Rev Bras Saúde Matern Infant 2011; 11(3):301-12.

17. Bacil EDA, Piola TS, Mazzardo O, Legnani RFS, Campos W de. Validade e fidedignidade de escalas de apoio social e autoeficácia para atividade física em escolares. Rev Andaluza Med del Deport 2016; 6-11.

18. Farias Júnior JC, Lopes A, Mota J, Santos MP, Ribeiro JC, Hallal PC. Validade e reprodutibilidade de um questionário para medida de atividade física em adolescentes: uma adaptação do Self-Administered Physical Activity Checklist. Rev Bras Epidemiol 2012; 15(1):198-210.

19. Sallis JF, Strikmiller PK, Harsha DW, Feldman HA, Ehlinger S, Stone EJ, et al. Validation of interviewer- and self-administered physical activity checklists for fifth grade students. Med Sci Sports Exerc 1996; 28:840-851.

20. WHO. Global recommendations on physical activity for health. Geneva. 2010; 60.

21. Bacil EDA, Piola TS, Campos W de, Watanabe PI, Silva MP, Legnani RFS. Reprodutibilidade de um questionário de atividade física em escolares de 9 a 15 anos de idade. Cien Saude Colet 2018;23(11):3841-3848.

22. Lee IM, Shiroma EJ, Lobelo F, Puska P, Blair SN, Katzmarzyk PT, et al. Effect of physical inactivity on major non-communicable diseases worldwide: An analysis of burden of disease and life expectancy. Lancet 2012; 380(9839): 219-229.

23. Harding SK, Page AS, Falconer C, Cooper AR. Longitudinal changes in sedentary time and physical activity during adolescence. Int J Behav Nutr Phys Act 2015; 12(44):1-7.

24. Gonçalves H, Hallal PC, Amorim TC, Araújo CLP. Fatores socioculturais e nível de atividade física no início da adolescência. Rev Panam Salud Publica 2007; 22(4): 246-253. 
25. Maturo CC, Cunningham SA. Influence of Friends on Children's Physical Activity :A Review. Am J Public Health 2013; 103(7):23-38.

26. Kirby J, Levin KA, Inchley J. Parental and Peer Influences on Physical Activity Among Scottish Adolescents: A Longitudinal Study. J of Phys Act and Heal 2011; 8: 785-793

27. Seabra AF, Mendonça DM, Thomis MA, Anjos LA, Maia JA. Determinantes biológicos e sócio-culturais associados à prática de atividade física de adolescentes. Cad Saúde Pública 2008; 24(4):721-736.

28. Hearst MO, Patnode CD, Sirard JR, Farbakhsh K, Lytle LA. Multilevel predictors of adolescent physical activity: a longitudinal analysis. Int $\mathrm{J}$ of Behav Nut and Phys Act. 2012; 9(8): 1-10.

29. Papalia DE, Feldman RD. Desenvolvimento humano. Porto Alegre: AMGH, 2013.

30. Gallahue D1, Ozmun JC, Goodway JD. Compreendendo o desenvolvimento motor: bebê, crianças, adolescentes e adultos. Porto Alegre: AMGH, 2013.

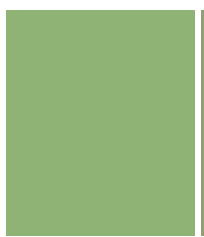

Corresponding author

Jhonatan Gritten Campos

Federal University of Parana, Postgraduate

Program in Physical Education.

Rua Coração de Mari, 92. Jardim Botânico,

ZIP Code: 80215-370, Curitiba/PR, Brazil.

Email: jhona_tan2011@hotmail.com 